\title{
DESAIN PEMBELAJARAN BERBASIS ANDROID BERBANTU SMART APPS CREATOR (SAC) PADA PELAJARAN BERMUSIK
}

\author{
Dwi Dani Apriyani', Vickry Ramdhan² \\ ${ }^{1,2}$ Universitas Indraprasta PGRI \\ Jl. Raya Tengah No. 80, Kel. Gedong, Kec. Pasar Rebo, Jakarta Timur 13760 \\ 1dwidani12@gmail.com 2vickry.ramdhann@gmail.com
}

\begin{abstract}
ABSTRAK
Kegiatan belajar mengajar tak luput dari perkembangan teknologi. Dalam kondisi pembelajaran daring, diperlukan adanya media pembelajaran yang dapat membantu menyampaikan informasi dari guru kepada siswa. desain pembelajaran berbasis android dapat membantu siswa memahami pelajaran yang disampaikan oleh guru. Aplikasi yang dibuat menggunakan Smart Apps Creator dapat dioperasikan oleh guru untuk menjadikan proses belajar semakin interaktif. Tujuan dari penelitian ini adalah untuk menghasilkan produk berupa aplikasi yang dapat digunakan sebagai media belajar oleh siswa. Sehingga dapat memiliki kegunaan membantu guru dalam penyampaian materi bermusik. Metode penelitian pada penelitian ini ialah research and development. Dari hasil penelitian, didapatkan bahwa respon ahli terhadap desain pembelajaran berbasis android berbantu smart Apps Creator pada Pelajaran bermusik mendapatkan kategori sangat baik. Dan selanjutnya dilakukan uji respon siswa yang mendapatkan kategori sangat baik. Maka dapat disimpulkan bahwa desain pembelajaran berbasis android berbantuan Smart Apps Creator sudah layak digunakan sebagai bahan ajar oleh siswa.
\end{abstract}

Kata Kunci: Desain Pembelajaran, Android, Smart Apps Creator.

\begin{abstract}
Teaching and learning activities are inseparable from technological developments. In bold learning conditions, it is necessary to have learning media that can help convey information from teachers to students. Android-based learning design can help students understand the lessons delivered by the teacher made by Smart Apps Creator can be operated by the teacher to make the learning process interactive. From the results of the study, it was found that the expert's response to the android-based learning design assisted by the Smart Apps Creator in music lessons got a very good category. And then test the responses of students who get a very good category. So it can be said that the learning design based on Android Smart Apps Creator is feasible to be used as learning material by students.
\end{abstract}

Key Word: Learning Desaign, android, Smart Apps Creator.

\section{PENDAHULUAN}

Menyerbarnya virus corona pada penduduk dunia dan Indonesia berdampak pada kebijakan baru dalam pembatasan interaksi dan kerumunan (Assidiqi \& Sumarni, 2020). Pendidikan termasuk bagian yang diharuskan pemerintah untuk membatasi kegiatan berkerumun. Hampir sebagian besar instansi pendidikan melakukan pembelajaran secara daring(Handaini \& Zulfah, 2021). Pembelajaran secara daring dilakukan menggunakan aplikasi pihak ketiga untuk menjembatani komunikasi dan penyampaian materi dari guru kepada siswa (Maulana, 2021).

Alat atau aplikasi yang digunakan sebagai media pembelajaran harus disesuaikan dengan materi pembelajaran dan kesiapan siswa (Yulistyanti, Farkhatin, \& Mustari, 2021).
Pendidikan yang berpusat pada siswa akan memberikan hasil yang lebih efektif karena menyesuaikan cara siswa dalam memahami pelajaran (Demirtas \& Egilmez, 2018). Media yang digunakan dalam kegiatan belajar mengajar diharapkan dapat menumbuhkan perasaan senang pada siswa untuk mengikuti pembelajaran serta dapat menumbuhkan perhatian lebih baik dalam diri siswa (Rikonurrohim, 2017). Berbagai aspek dapat dimasukkan ke dalam media belajar, seperti suara, animasi, gambar dan tautan pendukung (Ridwan, 2020). Penggunaan media belajar akan lebih optimal jika didukung dengan gawai yang mudah digunakan dan sesuai.

Peneliti membuat desain pembelajaran berbasis android berbantuan Smart Apps Creator sebagai wadahnya. Sistem operasi android yang tidak memberatkan pengguna 
ini memiliki perkembangan yang pesat dalam tersebarnya aplikasi dalam android (Widiastika, Hendracipta, \& Syachruroji, 2020). Aplikasi desktop ini dapat digunakan untuk membuat aplikasi android tanpa kode pengaman. Smart Apps Creator atau SAC dapat digunakan tanpa harus menguasai bahasa pemograman tertentu sehingga memudahkan para user khususnya dalam hal ini adalah guru (Yuberti, Wardhani, \& Latifah, 2021). Dengan menggunakan Smart Apps Creator dapat menyisipkan lagu, gambar, animasi dan lainnya maka Smart Apps Creator dapat menciptakan materi lebih interaktif dan lebih menarik perhatian siswa (Khasanah, Muhlas, \& Marwani, 2020).

Penelitian ini bertujuan untuk menghasilkan produk berupa aplikasi yang dapat digunakan sebagai media belajar oleh siswa. Sehingga dapat memiliki kegunaan membantu guru dalam penyampaian materi bermusik, dapat meningkatkan minat siswa dalam mengikuti pelajaran bermusik dan dapat meningkatkan kemampuan belajar siswa dalam bermusik.

Sebelumnya telah dilakukan penelitian oleh Fariz Krisna Syahputra dengan judul Pengembangan media pembelajaran interaktif berbasis android menggunakan Smart Apps Creator (SAC) untuk mata pelajaran Animasi 2D \& 3D kelas XI di SMKN 1 Driyorejo Gresik. Dari penelitian tersebut didapatkan bahwa masalah yang terjadi adalah belum adanya media belajar pada mata pelajaran animasi 2D \& 3D. Hasil riset memperoleh bahwa uji validitas media valid dan media pembelajaran interaktif animasi 2D \& 3D yang berisi android cocok digunakan dan layak menjadi media belajar bagi para siswa (Syahputra \& Prismana, n.d.). Penelitian Pelatihan Pembuatan Media Pembelajaran menggunakan Aplikasi Smart Apps Creator di SMK Negeri 2 Pinggir dilakukan oleh Sutejo dan Yogi menemukan permasalahan bahwa sekolah tersebut belum menggunakan media belajar mobile learning. Peneliti menawarkan solusi dengan menghadirkan media pembelajaran virtual guna menjadikan pembelajaran yang interaktif, menarik perhatian dan antusias siswa. Dengan dilakukannya pelatihan pembuatan media pembelajaran menggunakan Aplikasi Smart Apps Creator telah mampu meningkatkan pengetahuan guru tentang perkembangan media pembelajaran dan meningkatkan kemampuan guru dalam mengoperasikan computer atau laptop (Sutejo \& Yogi Ersan Fadrial, 2021).

\section{METODE PENELITIAN}

Metode penelitian pada penelitian ini ialah research and development. Penelitian ini dikembangkan dengan proses atau syarat yang akan meningkatkan produk dari studi pembelajaran.

Penelitian ini dilakukan pada siswa sekolah menengah pertama pada pelajaran bermusik. Langkah penelitian yang dilakukan ialah, pertama, tahap pengumpulan informasi yang dilakukan dengan observasi pada lingkungan sekolah. Kemudian tahap pengembangan produk awal. Dan kini ditawarkan solusi yakni desain pembelajaran berbasis android pada pembelajaran musik. Tahap ketiga yaitu memvalidasi produk yang telah dibuat. Tahap keempat, uji coba produk yang dilaksanakan pada siswa. Tahap kelima yaitu tahap produk akhir berupa aplikasi yang akan digunakan siswa.

\section{HASIL DAN PEMBAHASAN}

Penelitian ini membuat produk aplikasi berbasis android menggunakan Smart Apps Creator yang membantu siswa dalam mempelajari musik. Peneliti berharap siswa dapat belajar musik dengan menyenangkan dari aplikasi ini, sehingga aplikasi ini dapat dijadikan media belajar yang tepat bagi pelajaran bermusik. Dalam tahap analisis peneliti mengumpulkan informasi kompetensi apa saja yang harus dicapai. Dalam penelitian ini peneliti mendapatkan informasi berupa silabus atau RPS. Selanjutnya tahap desain akan dibuat berdasarkan data yang diperoleh dari hasil analisis. Kemudian tahap pengembangan yaitu menerjemahkan rancangan ke dalam bentuk dokumen seperti rencana tampilan aplikasi dan isi. Dalam tahap produksi digunakan aplikasi Smart Apps Creator. Berikut ini halaman pembuka pada aplikasi 


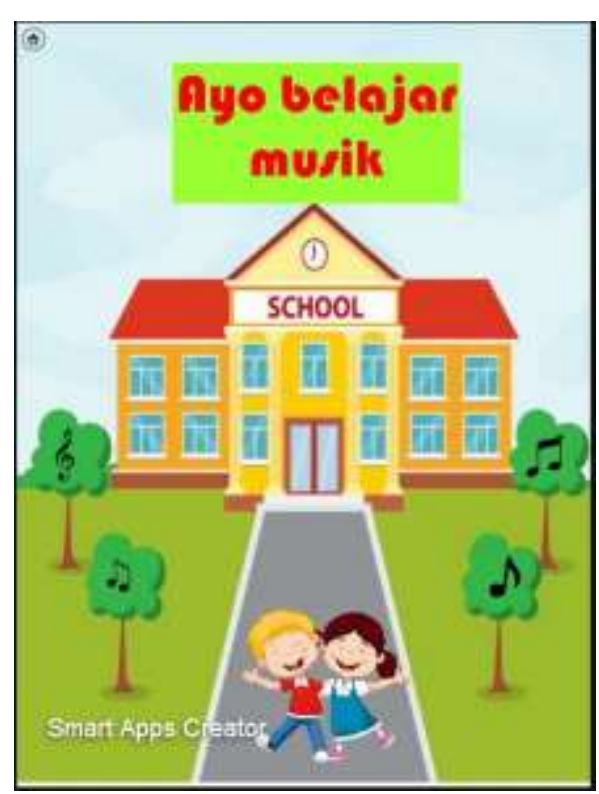

Gambar 1. Halaman utama

Dalam tahap validasi digunakan kriteria kelayakan Arikunto (Khasanah et al., 2020), sebagai berikut:

Tabel 1. Skor penilaian validasi ahli

\begin{tabular}{ccc}
\hline No & Presentasi & kriteria \\
\hline 1. & $81 \%-100 \%$ & Sangat Layak \\
2. & $61 \%-80 \%$ & layak \\
3 & $41 \%-60 \%$ & Cukup layak \\
4 & $21 \%-40 \%$ & Kurang layak \\
5 & $<21 \%$ & Sangat tidak layak \\
\hline
\end{tabular}

Hasil uji coba dari 3 ahli yang didapat peneliti adalah $78 \%$ dengan rekapitulasi sebagai berikut:

\begin{tabular}{ccc}
\multicolumn{3}{c}{ Tabel 2. Skor penilaian validasi ahli } \\
\hline No & resp & nilai \\
\hline 1. & Ahli 1 & $75 \%$ \\
2. & Ahli 2 & $77 \%$ \\
3 & Ahli 3 & $78 \%$ \\
& Rata-rata & $77 \%$ \\
\hline
\end{tabular}

Maka dapat dikatakan bahwa aplikasi tersebut dikategorikan "layak".

Uji coba kemudian dilanjutkan pada kelompok kecil dengan hasil $82 \%$ yang dapat dikategorikan "sangat layak". Berikut rekapitulasi

\begin{tabular}{ccc}
\multicolumn{3}{c}{ Tabel 2. Skor penilaian validasi ahli } \\
\hline No & resp & nilai \\
\hline 1. & Resp 1 & $80 \%$ \\
2. & Resp 2 & $82 \%$ \\
3 & Resp 3 & $80 \%$ \\
4 & Resp 4 & $84 \%$ \\
5 & Resp 5 & $85 \%$ \\
6 & Resp 6 & $82 \%$ \\
7 & Resp 7 & $85 \%$ \\
8 & Resp 8 & $80 \%$ \\
9 & Resp 9 & $80 \%$ \\
10 & Resp 10 & $80 \%$ \\
& total & $82 \%$ \\
\hline
\end{tabular}

Desain pembelajaran berbasis android ini berorientasi pada pembelajaran musik. Awalnya peneliti melihat adanya ketidaktertarikan siswa pada pelajaran bermusik. Sebelumnya, para siswa merasa kesulitan memahami pelajaran musik dalam proses belajar daring, dengan begitu minat belajar mereka juga menurun. Sehingga dengan ditawarkannya desain pembelajaran berbasis android membantu siswa memahami dan mempelajari musik. Sehingga dilakukan analisis dan dari hasil penelitian didapatkan bahwa siswa membutuhkan aplikasi sebagai media belajar bermusik untuk mencapai tujuan pembelajaran di sekolah.

\section{SIMPULAN DAN SARAN}

Berdsasarkan hasil ahli dan uji coba pada siswa dikategorikan memperoleh hasil yang layak, sehingga desain pembelajaran berbasis android ini dinyatakan layak secara konseptual dan dapat digunakan sebagai media pembelajaran bermusik pada siswa menengah pertama. Saran bagi penelitian berikutnya, ialah: perlu dikembangkan lebih lanjut dalam kuis dan ditekankan alur berpikir kreatif siswa. selanjutnya juga dapat diteruskan hingga keefektifan produk dalam kegiatan belajar mengajar.

\section{DAFTAR PUSTAKA}

Assidiqi, M. H., \& Sumarni, W. (2020). Pemanfaatan Platform Digital di Masa Pandemi Covid-19. Prosiding Seminar Nasional Pascasarjana, 298-303. Retrieved from https://proceeding.unnes.ac.id/index.ph p/snpasca/article/download/601/519

Handaini, M., \& Zulfah, Z. (2021). Penerapan e-Learning melalui Media Schoology untuk Meningkatkan Motiasi Belajar Siswa SMP Negeri 3 Tapung. Mathema: Jurnal Pendidikan Matematika, 3(1), 16. https://doi.org/10.33365/jm.v3i1.993

Khasanah, K., Muhlas, M., \& Marwani, L. (2020). Development of E-Learning Smart Apps Creator (Sac) Learning Media for Selling Employees on Paid Tv. Akademika, 9(02), 129-143. https://doi.org/10.34005/akademika.v9i 02.819

Maulana, H. A. (2021). Persepsi Mahasiswa terhadap Pembelajaran Daring di Pendidikan Tinggi Vokasi: Studi Perbandingan antara Penggunaan 
Google Classroom dan Zoom Meeting. Edukatif: Jurnal Ilmu Pendidikan, 3(1), 188-195.

https://doi.org/10.31004/edukatif.v3i1.2 59

Ridwan. (2020). Belajar Melalui Musik Dengan Menerapkan Metode Orff. 4(1), 112-122.

https://doi.org/10.31849/paud-lectura.v

Rikonurrohim, M. (2017). Pengaruh Media Audio Visual Pada Pembelajaran Musik Ensambel Kelas Viii Di Smp Negeri 5 Pariaman. E-Jurnal Sendratasik, 6(1), 55-61. Retrieved from https://drive.google.com/file/d/140MvX XgerKfNOd3WKKqBcjbxV7UeKPHr/v iew

Sutejo, \& Yogi Ersan Fadrial. (2021). Pelatihan Pembuatan Media Pembelajaran Menggunakan Aplikasi Smart Apps Creator Di Smk Negeri 2 Pinggir. J-COSCIS: Journal of Computer Science Community Service, 1(2), 45-52. https://doi.org/10.31849/jcoscis.v1i2.72 15

Syahputra, F. K., \& Prismana, I. G. L. P. E. (n.d.). Pengembangan Media Pembelajaran Interaktif Berbasis Android 3D Kelas Xi Di Smkn 1 Driyorejo Gresik. 5(2), 763-768.

Widiastika, M. A., Hendracipta, N., \& Syachruroji, A. (2020). Pengembangan Media Pembelajaran Mobile Learning Berbasis Android Pada Konsep Sistem Peredaran Darah di Sekolah dasar. Jurnal Basicedu, 5(1), 47-64. https://doi.org/10.31004/basicedu.v5i1. 602

Yuberti, Wardhani, D. K., \& Latifah, S. (2021). Pengembangan Mobile Learning Berbasis Smart Apps Creator Sebagai Media Pembelajaran Fisika. Physics and Science Education Journal (PSEJ), 1(2), 90-95.

Yulistyanti, D., Farkhatin, N., \& Mustari, D. (2021). Penggunaan Aplikasi Sebagai Media E-Learning Remaja Di Karang Taruna. Journal of Empowerment, 2(1), 89.

https://doi.org/10.35194/je.v2i1.1265 